\title{
Analgesic efficacy of transversus abdominis plane block in neonates and early infants for colostomy and reversal of colostomy
}

\author{
Yenidoğanlar ve küçük çocuklarda kolostomi ve kolostominin kapatılması sırasında \\ uygulanan transversus abdominis plan bloğun analjezik etkinliği
}

\section{Chee Kean CHEN, ${ }^{1}$ Shu Ching TEO, ${ }^{2}$ Vui Eng PHUI, ${ }^{3}$ Mat Ariffin SAMAN ${ }^{2}$}

\begin{abstract}
Summary
The application of ultrasound-guided transversus abdominis plane (TAP) block in paediatric population is gaining popularity among anaesthetists. We present a case series of ultrasound-guided TAP block in ten neonate and infants undergoing colostomy and reversal of stoma. Classical TAP as described by Hebbard was carried out and a maximum dosage of $1 \mathrm{ml} / \mathrm{kg}$ of $0.25 \%$ levobupivacaine was injected. Pain score was assessed using Neonatal Infant Pain Scale for 24 hours. In all patients, the block was successful with minimal hemodynamic changes intraoperatively and no additional systemic analgesia was needed intraoperative and immediate postoperatively. Ultrasound-guided TAP block has an important role in providing safe and effective analgesia for colostomy creation and reversal of stoma surgeries in paediatric population.
\end{abstract}

Keywords: Colostomy; paediatric surgery; transversus abdominis plane block.

\begin{abstract}
Özet
Pediyatrik hastalarda ultrason eşliğinde transversus abdominis plan (TAP) bloğu anestezistler arasında popülarite kazanmaktadır. Kolostomi ve stomanın kapatılması sırasında 10 yenidoğan ve bebekte ultrason eşliğinde TAP bloğu olgu çalışmasını sunuyoruz. Hebbard tarafından tanımlanan klasik TAP uygulandı ve maksimum $1 \mathrm{ml} / \mathrm{kg}$ dozda $\% 0.25$ levobupivakain enjekte edildi. Yenidoğan Ağrı Ölçeği kullanılarak 24 saat boyunca ağıı skorları değerlendirildi. Hastaların hepsinde minimal hemodinamik değişikliklerle blok başarılı oldu, ameliyat sırasında ve erken ameliyat sonrası dönemde ilave sistemik analjeziğe gerek duyulmadı. Kolostomi oluşturma ve stomayı kapatma için ultrason eşliğinde TAP bölümoğu güvenli ve etkili analjezi sağlamada önemli bir role sahiptir.

Anahtar Kelimeler: Kolostomi; pediyatrik cerrahi; transversus abdominis plan bloğu.
\end{abstract}

\section{Introduction}

Post-surgical anterior abdominal pain is very common and it causes significant morbidity among patients undergoing abdominal surgery. ${ }^{[1,2]}$ Even most recently, providing adequate pain relief for postoperative pain remains a challenge for both surgeons and anaesthetists, especially in paediatric patients, where postoperative apnoea is a major concern when opioids are administered ${ }^{[3]}$ Inadequate postoperative pain relief on the other hand will cause significant hardship to children, parents and nurses during postoperative recovery. ${ }^{[4]}$ Recent advancement in ultrasound-guided regional anaesthesia (USRA) has led to a safer and more precise practice in providing analgesia. This is especially true for the management of postoperative abdominal pain when transversus abdominis plane (TAP) block was introduced a few years ago. ${ }^{[5]}$

\section{'Department of Anesthesiology, Kuching Specialist Hospital, Kuching, Malaysia ${ }^{2}$ Department of Anesthesiology, Sarawak General Hospital, Kuching, Malaysia ${ }^{3}$ Department of Internal Medicine, Sarawak General Hospital, Kuching, Malaysia Submitted: 15.09.2013 Accepted after revision: 21.07.2014}

Correspondence: Dr. Chee Kean Chen. Lot 10420, Block 11, Tabuan Stutong Commercial Centre 93856 Kuching, Malaysia. Tel: +60 - 125255262 e-mail: chenck@hotmail.my

(c) 2015 Turkish Society of Algology 

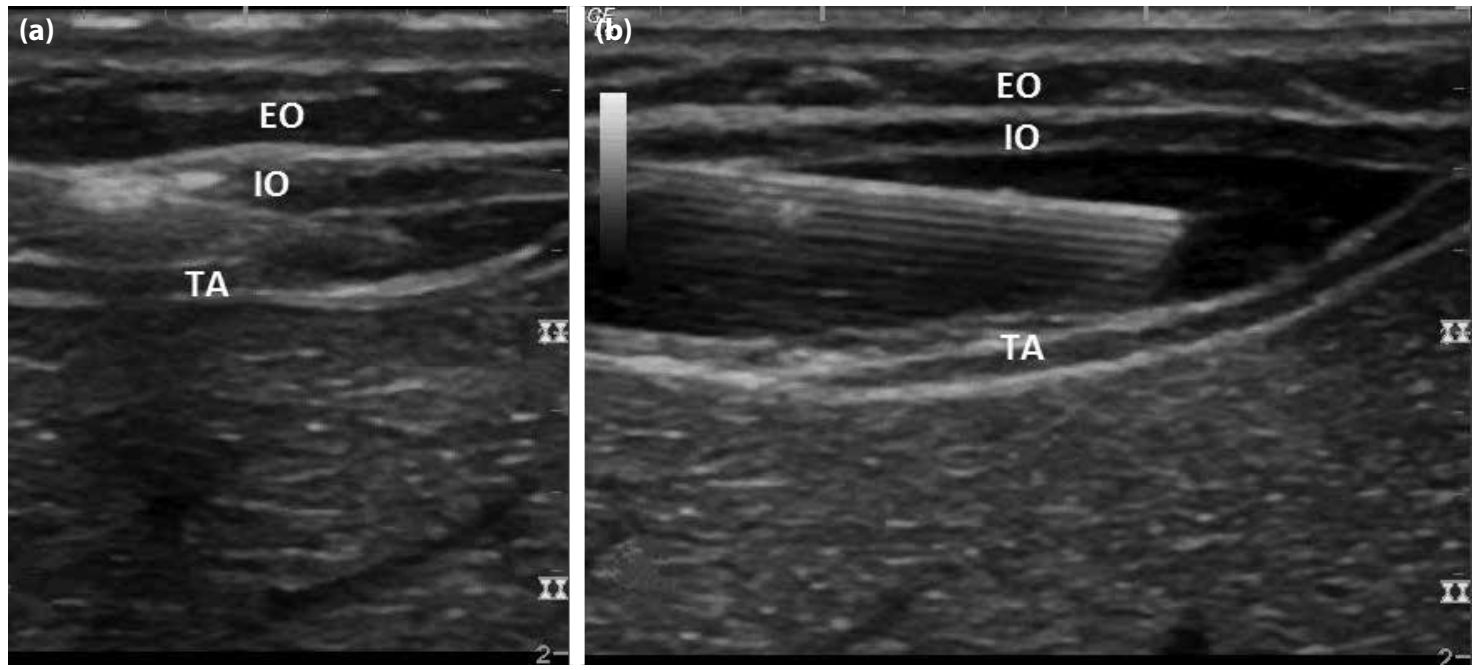

Figure 1. (a) Ultrasonography of anterior abdominal wall during initial needle insertion. (b) Ultrasonography of anterior abdominal wall when injectate separates internal oblique and transversus abdominis muscle. EO: External oblique muscle; IO: Internal oblique muscle; TA: Transversus abdominis muscle.

TAP block was routinely performed in our institution for certain short surgeries in adult patients, e.g.: appendicectomy, cholecystectomy, colostomy and reversal of colostomy. After obtaining favourable postoperative outcomes in adult patients, we extended the application of ultrasound-guided TAP block to paediatric patients undergoing short surgical procedures. Reports on the application of TAP block among paediatric patients are still not widely available, especially among neonates and young infants. This case series is a review of analgesic efficacy of TAP block in 5 neonates and 5 infants below 10 months-old. Procedures included were colostomy $(n=7)$, reversal of colostomy $(n=2)$ and revision of colostomy $(n=1)$.

\section{Case Report}

The present study with its included procedures was approved by Institutional Ethic Committee. This study evaluated the analgesic efficacy of ultrasoundguided TAP block for neonates and infants undergoing colostomy and reversal of colostomy was carried out from January 2011 to December 2012. After fulfilling the inclusion criteria, patient's parents were informed about risk and benefit of TAP, a part from risk of general anesthesia. The informed risk of TAP block included inadvertent puncture of intra-abdominal organ, bleeding, infection, inadequate postoperative pain relief and failure of block. Written informed consents were obtained from patients' parents. Exclusion criteria were patients allergic to amino-amide local anaesthetics, presence of coagulopathy, local skin in- fection at the needle puncture sites, and conversion of the above 2 procedures to major laparatomy.

Patient 1 to 4 was term neonates with the diagnoses of imperforated anus. Right transverse colostomy was carried out within 24 hours post-delivery. Patient 5 and 6 were diagnosed to have Hirsprung's disease and colostomy was done during early infancy. Patient 7 to 9 had correction anorectal surgery previously and reversal of colostomy was done. Patient 10 with the diagnosis of imperforated anus had collapsed and malfunctioning stoma and revision of colostomy was done.

TAP blocks were placed after induction of general anaesthesia, either with sevoflurane or propofol induction, followed by atracurium for intubation. Under aseptic technique, either linear array probe (GE 12L-RS 5-13.0 MHz, GE LOGIQ $\mathrm{e}^{\circledR}$, GE Healthcare, UK) or 'hockey stick' ultrasound probe (GE i12L-RS 4-10 $\mathrm{MHz}, \mathrm{GE}$ LOGIQ $\mathrm{e}^{\circledast}$, GE Healthcare, UK) was placed on the area between costal margin and iliac crest, along anterior axillary line to identified all layers of abdominal muscles. With 'in-plane' technique by using short bevel 24-gauge 1 inch Plexufix (B. Braun, Melsungen AG, Germany) was introduced from lateral side of ultrasound probe. Once the anatomy was ascertained, the needle was advanced under ultrasound guidance with the needle tip visualised at all times (Figure 1). With the tip observed in the TAP, a maximum amount $1 \mathrm{ml} / \mathrm{kg}$ of $0.25 \%$ levobupivacaine (Abbott, Elverum, Norway) was injected. 
The primary endpoints were pain scores using Neonatal Infant Pain Scale (NIPS) at immediately postoperative, and at 12 hours. NIPS is a pain assessment tool which encompasses six parameters (facial expression, cry, breathing patterns, arms, legs and state of arousal), as summarized in Table $1 .{ }^{[6]}$ Each parameter comprised of a scoring system, which sum up to either a minimum score of 0 or maximum score of 7 . No complications attributed to the block were noted. All hemodynamic parameters were stable intraoperatively and all the patients were extubated at surgery cessation. No opioid was administered intra- and postoperatively. Patients' characteristics, diagnosis, surgery performed and NIPS were summarized in Table 2.

\section{Discussion}

Abdominal surgery for anorectal anomaly in neonate is a common procedure. Traditionally intraoperative analgesia involves systemic opioid or regional anaesthesia either as an epidural blockade or local wound infiltration. ${ }^{[7]}$ Due to the immaturity of central nervous system, neonates are susceptible to respiratory depressant effect of systemic opioids, which can lead to apnea and necessitate ventilation or high dependency care postoperatively. ${ }^{[3]}$ Local wound infiltration technique has its limitation at a relatively low dose of local anaesthetic that can be used and hence requires lower concentration to achieve higher volumes. ${ }^{[8]}$ The assessment of pain intensity in paediatric patients has been debated over years and various methods of pain measurement have been developed. ${ }^{[9]}$ In our case series, postoperative pain assessment was performed with NIPS which was the most suitable methods for our patient's age group. ${ }^{[6]}$

The anterolateral abdominal wall receives its main nerve supply from the anterior rami of spinal nerves T7 to L1. Branches from the anterior rami include the intercostal nerves (T7-T11), the subcostal nerve (T12) and the iliohypogastric and ilioinguinal nerves (L1). All these branches subsequently give rise to lateral cutaneous and anterior cutaneous branches as they become more superficial. ${ }^{[10]}$ TAP block is a regional anaesthesia technique where local anaesthetic is injected into the neurovascular plane between the transversus abdominis and internal oblique muscles in the anterolateral abdominal wall. The classical or posterior TAP block which involves the injection of local anaesthetic at the anterior axillary line between
Table 1. Neonatal Infant Pain Scale (NIPS)

\begin{tabular}{|c|c|c|}
\hline Parameter & Finding & Points \\
\hline \multicolumn{3}{|c|}{ Facial expression } \\
\hline & Relaxed & 0 \\
\hline & Grimace & 1 \\
\hline \multicolumn{3}{|l|}{ Cry } \\
\hline & No cry & 0 \\
\hline & Whimper & 1 \\
\hline & Vigorous crying & 2 \\
\hline \multicolumn{3}{|c|}{ Breathing patterns } \\
\hline & Relaxed & 0 \\
\hline & Change in breathing & 1 \\
\hline \multicolumn{3}{|l|}{ Arms } \\
\hline & Restrained & 0 \\
\hline & Relaxed & 0 \\
\hline & Flexed & 1 \\
\hline & Extended & 1 \\
\hline \multicolumn{3}{|l|}{ Legs } \\
\hline & Restrained & 0 \\
\hline & Relaxed & 0 \\
\hline & Flexed & 1 \\
\hline & Extended & 1 \\
\hline \multicolumn{3}{|c|}{ State of arousal } \\
\hline & Sleeping & 0 \\
\hline & Awake & 0 \\
\hline & Fussy & 1 \\
\hline
\end{tabular}

NIPS: Total points for the 6 parameters, where minimum score is 0 and maximum score is 7 .

the lower costal margin and iliac crest, provides ipsilateral sensory blockade in the anterolateral abdominal wall. ${ }^{[5]}$ Various studies have demonstrated the efficacy of TAP block in providing effective postoperative analgesia in patients undergoing appendicectomy, ${ }_{1}^{[11]}$ hernia repair, ${ }^{[12]}$ cholecystectomy ${ }^{[13]}$ and caesarean delivery. ${ }^{[14]}$

The practice of TAP block in paediatric patients is still sparse. In 2009, both Tekin et al. and Jacobs et al. reported the application of TAP in a neonate in two separate case reports respectively. ${ }^{[15,16]}$ Subsequently, Jacobs et al. reported an audit finding of ten neonates and infants undergoing various surgeries with the application of TAP block. ${ }^{[17]}$ In current case series, which only involved patients undergoing colostomy and closure of colostomy, demonstrated that TAP block is effective and safe in neonates and 


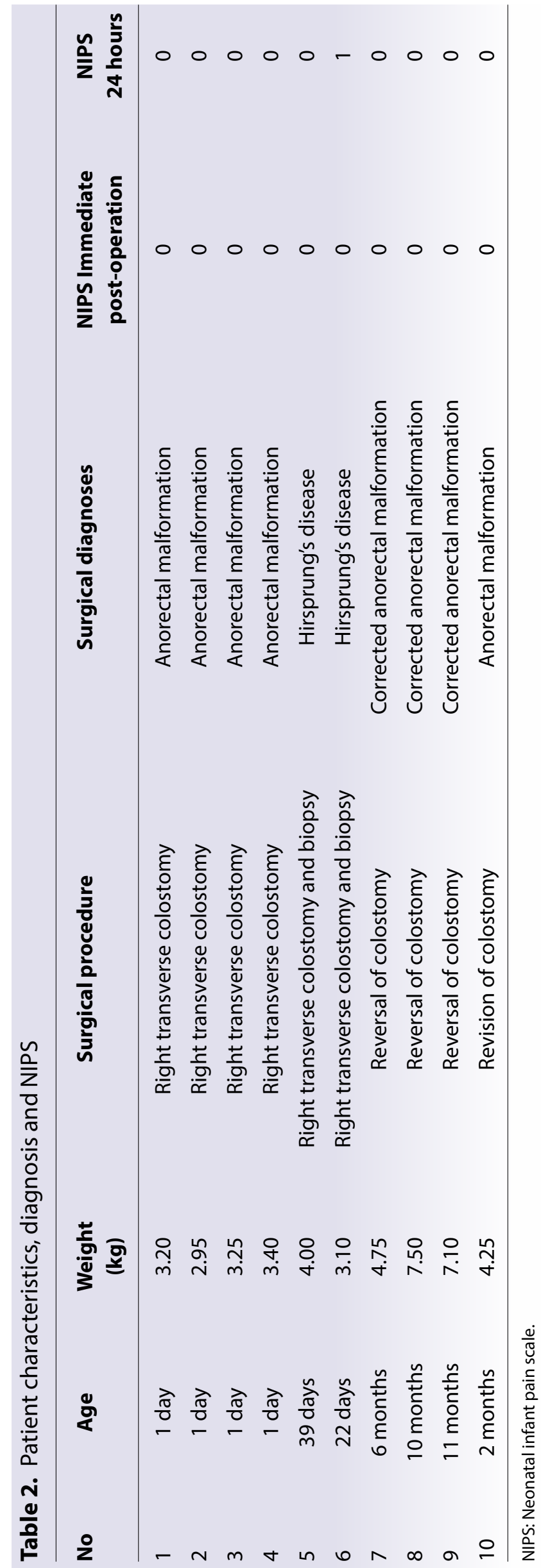

infants. Intra-operative haemodynamic parameters remained within acceptable limits and opioids were avoided. The advantages of this regional anaesthesia for paediatric patients include possible shorter extubation time, prevention of neuraxial blockade and complications and reduction or avoidance of opioids usage, subsequently preventing its side-effects. In the paediatric population, especially premature infants, postoperative apnea is always a major concern if opioid is administered.

TAP block in paediatric patients particularly, requires ultrasound imaging owing to thin tissue plane and close proximity of between skin and peritoneum. The needle-tip is within millimeters of the bowel and liver parenchyma. With real-time monitoring of needle-tip position, we can avoid unnecessary over puncture and inappropriate spread of local anaesthetic. Even though performing regional anaesthesia in paediatric patients is considered hazardous due to their small habitus by many anaesthetists, but under ultrasound guidance, the procedure is much safer and easier in paediatric patients where the tissue plane is thin, thus allowing better visual resolution of anatomy, compare to adult patients. Short bevel needles further enhanced precision of positioning of the needle-tip in TAP with 'fascial click! ${ }^{[18]}$

The limitations of this case series were the small sample size and non-placebo controlled study. Perhaps uniform procedures or surgeries would have added more value to this report. However, the encouraging results from this series merit a randomized placebo controlled trial to further validate this technique. We suggest that this practice should be encouraged with the presence of operators who are experienced in both neonatal and USRA to avoid unnecessary complications. In conclusion, TAP block provides a safe and effective analgesia for colostomy creation and reversal of stoma surgeries in the paediatric population.

\section{Acknowledgement}

The authors declare neither financial support nor any conflict of interest.

Conflict-of-interest issues regarding the authorship or article: None declared.

Peer-rewiew: Externally peer-reviewed. 


\section{References}

1. Macrae WA. Chronic pain after surgery. $\mathrm{Br} J$ Anaesth 2001;87(1):88-98.

2. Akkaya T, Ozkan D. Chronic post-surgical pain. Agri 2009;21(1):1-9.

3. Coté CJ, Karl HW, Notterman DA, Weinberg JA, McCloskey C. Adverse sedation events in pediatrics: analysis of medications used for sedation. Pediatrics 2000;106(4):633-44.

4. Kain ZN, Mayes LC, Caldwell-Andrews AA, Karas DE, McClain BC. Preoperative anxiety, postoperative pain, and behavioral recovery in young children undergoing surgery. Pediatrics 2006;118(2):651-8.

5. Hebbard P, Fujiwara Y, Shibata Y, Royse C. Ultrasound-guided transversus abdominis plane (TAP) block. Anaesth Intensive Care 2007;35(4):616-7.

6. Lawrence J, Alcock D, McGrath P, Kay J, MacMurray SB, Dulberg $C$. The development of a tool to assess neonatal pain. Neonatal Netw 1993;12(6):59-66.

7. Uguralp S, Mutus M, Koroglu A, Gurbuz N, Koltuksuz U, Demircan M. Regional anesthesia is a good alternative to general anesthesia in pediatric surgery: Experience in 1,554 children. J Pediatr Surg 2002;37(4):610-3.

8. Berde CB. Toxicity of local anesthetics in infants and children. J Pediatr 1993;122(5 Pt 2):14-20.

9. Bellieni CV. Pain assessment in human fetus and infants. AAPS J 2012;14(3):456-61.

10. Rozen WM, Tran TM, Ashton MW, Barrington MJ, Ivanusic JJ, Taylor Gl. Refining the course of the thoracolumbar nerves: a new understanding of the innervation of the an- terior abdominal wall. Clin Anat 2008;21(4):325-33.

11. Niraj G, Searle A, Mathews M, Misra V, Baban M, Kiani S, et al. Analgesic efficacy of ultrasound-guided transversus abdominis plane block in patients undergoing open appendicectomy. Br J Anaesth 2009;103(4):601-5.

12. Gürkan Y, Tekin M, Yirmibeşoğlu AO, Aysu Salviz E. Bilateral transversus abdominus plane block for incisional hernia repair. Agri 2011;23(3):134-5.

13. Chen CK, Tan PC, Phui VE, Teo SC. A comparison of analgesic efficacy between oblique subcostal transversus abdominis plane block and intravenous morphine for laparascopic cholecystectomy. A prospective randomized controlled trial. Korean J Anesthesiol 2013;64(6):511-6.

14. McDonnell JG, Curley G, Carney J, Benton A, Costello J, Maharaj $\mathrm{CH}$, et al. The analgesic efficacy of transversus abdominis plane block after cesarean delivery: a randomized controlled trial. Anesth Analg 2008;106(1):186-91.

15. Tekin $M$, Gurkan $Y$, Solak M, Toker K. Ultrasound-guided bilateral transversus abdominis plane block in a 2-monthold infant. J Anesth 2009;23(4):643-4.

16. Jacobs A, Thies KC. Ultrasound-guided transversus abdominis plane block for reversal of ileostomy in a 2-kg premature neonate. Paediatr Anaesth 2009;19(12):1237-8.

17. Jacobs A, Bergmans E, Arul GS, Thies KC. The transversus abdominis plane (TAP) block in neonates and infants - results of an audit. Paediatr Anaesth 2011;21(10):1078-80.

18. Tsui BC, Suresh S. Ultrasound imaging for regional anesthesia in infants, children, and adolescents: a review of current literature and its application in the practice of neuraxial blocks. Anesthesiology 2010;112(3):719-28. 